УДК 378.147:347.96(477)

DOI:

Галина Білавич, доктор педагогічних наук, професор кафедри педагогіки початкової освіти ДВНЗ “Прикарпатський національний університет імені Василя Стефаника”

Наталія Мукан, доктор педагогічних наук, професор, професор кафедри педагогіки та інноваційної освіти Національного університету “Львівська політехніка"

\title{
КУЛЬТУРА УКРАЇНСЬКОГО МОВЛЕННЯ МАЙБУТНІХ ПРАВОЗНАВЦІВ КРІЗЬ ВИМІР ЕРИСТИКИ
}

Стаття присвячена проблемі формування культури украӥнського мовлення майбутніх правознавців. Автори акцентують на еристиці як розділі риторики, у процесі вивчення якої студенти-юристи не тільки здобувають знання про способи переконання, ефективні форми мовленнєвого впливу на аудиторію, а й про полемічне мистецтво, глибше дізнаються про діалогічне мовлення, а також формують уміння вести суперечку. Базовими у прочесі професійної мовленнєвої підготовки майбутніх правознавиів мають стати знання про нормативність украӥнського мовлення, його культуру, еристику, а також уміння вести розгорнутий монолог з фахової проблематики, виробити власний ораторський стиль, виголошувати промову з використанням невербальних засобів впливу на аудиторію, уміння вести діалог, полілог, використовувати мовленнєвий етикет тощу.

Ключові слова: майбутні правознавиі; культура украйнського мовлення; еристика; діалог; професійна підготовка.

Табл. 2. Літ. 5.

Halyna Bilavych, Doctor of Sciences (Pedagogy), Professor of the Pedagogy of Primary Education Department, State Pedagogical University "Vasyl Stefanyk Precarpathian National University"

Nataliya Mukan, Doctor of Sciences (Pedagogy), Professor, Professor of the Pedagogy and Innovative Education Department, Lviv Polytechnic National University

\section{THE UKRAINIAN SPEECH CULTURE OF FUTURE JURISTS THROUGH THE PRISM OF HEURISTICS}

The article dwells upon the problem of Ukrainian speech culture formation of future jurists. The authors emphasize heuristics as a branch of rhetoric which is studied by law students who in this way obtain knowledge not only about persuasion, effective forms of speech influence on an audience, but also of the art of polemic, learn about dialogue speech in depth, form skills of running an argument. The art of polemic as a type of eloquence is very old. Heuristics as a kind of oratory was originated in the Ancient Greece. The art of running an argument is more complex kind of oratory than monologue eloquence. Heuristics as a rhetoric of the dialogue speech is represented in the following genres: discussion, polemic, dispute, debates, argument, etc. It is of a particular importance for future jurists since effective running of professional discussions leads to successful resolution of certain professional problems, prevents escalation of a conflict between parties, etc. This raises the question of a proper conduct of an argument which, first and foremost, relates to the psychology of running an argument (discussion, debates, dispute, etc.), especially speech culture of discussions, observance of speech etiquette. It is important to teach future jurists the culture of running arguments and use of non-offensive, diplomatic wording, as well as develop the skills to concisely express their opinion. While familiarizing the law students with the rules of conducting arguments, they need to be exposed to the criteria of self-evaluation of their speech skills. In the beginning of professional training, it is important to draw the future specialists' attention to difficulties which might arise in the process of the speech activity. Rhetoric of the dialogue speech has developed certain rules, techniques, and culture of heuristics which also have to be introduced to the future jurists. The article presents some of these aspects. These "golden rules of heuristics" should become the foundation to form the Ukrainian speech culture of a future specialist in the field of jurisprudence.

Keywords: future jurists; Ukrainian speech culture; heuristics; dialogue; professional training.

$\Pi$ остановка проблеми. Сучасні тенденції у розвитку системи вищої освіти вимагають постійного перегляду концептуальних і технологічних підходів до підготовки фахівців. Гуманізація, гуманітаризація освіти, ідеї особистісної та соціальної орієнтованості у вищій освіті, шляхи формування активної особистості, здатної самостійно робити вибір, ставити і реалізовувати цілі, що виходять за межі, визначені освітніми стандартами, усвідомлено оцінювати свою діяльність - ось ті пріоритети, які визначають концептуальні положення сучасної освіти.

Вагоме місце у підготовці майбутнього
Г. Білавич, Н. Мукан, 2020 
правознавця нового покоління теоретики і практики відводять гуманітарним предметам, дисциплінам мовно-літературного циклу, риториці тощо. Саме риторичні вміння як важливий складник загальної і професійної культури майбутніх юристів допоможуть, окрім іншого, ефективно організовувати юридичний процес, будувати переконливу комунікацію зі споживачами юридичних послуг, колегами, громадськістю тощо. Ці професійні вміння необхідні правознавцеві, позаяк спілкування, слово - це його основні інструменти в професійній діяльності [2; 5]. Тому актуальності набуває проблема формування культури українського мовлення, риторичних умінь майбутніх юристів у процесі їхньої професійної підготовки в закладі вищої освіти (ЗВО), оскільки їі успішне розв'язання слугуватиме підвищенню ефективності їхньої фахової діяльності, сприятиме більш повній самореалізації особистості, розвитку індивідуальності.

Аналіз останніх досліджень і публікацій. Попри те, що окремі аспекти порушеної проблеми знайшли відображення у працях Н. Бабич, Н. Бібік, П. Біленчук, Н. Волкової, І. Срмакова, I. Зимньої, Н. Кічук, С. Клепко, Н. Ничкало, О. Овчарук, А. Хуторського та ін. (компетентнісний підхід у професійній підготовці); С. Алексєєв, I. Бенедик, П. Біленчук, В. Горшенєв, С. Гусарев, А. Жалінський, А. Пиголкіна, О. Скакун, С. Сливка та ін. вивчали історичні, культурологічні, психологічні, порівняльно-правові аспекти юридичної діяльності; більш грунтовно проаналізували комунікативну культуру як складник професійної компетентності майбутніх правознавців А. Білоножко, Г. Бояринцева, 3. Височан, М. Криськів, В. Савіщенко, В. Тюріна, О. Тюрін, О. Уваркіна, Г. Яворська та ін., однак учені не акцентували на формуванні мовленнєвої культури майбутніх юристів у процесі вивчення еристики як розділу риторики.

Мета статті - схарактеризувати окремі засоби формування культури українського мовлення майбутніх правознавців.

Виклад основного матеріалу. Риторика як наука про способи переконання, ефективні форми мовленнєвого впливу на аудиторію з урахуванням iii особливостей, як теорія та майстерність ефективного (доцільного, впливового, переконливого, гармонійного) мовлення, що має предметом вивчення загальні закономірності мовленнєвої поведінки, які діють за різних ситуацій спілкування і у сферах діяльності, та практичні можливості використання їх з метою створення ефективного висловлювання, посідає одне 3 ключових місць у системі професійної підготовки майбутніх правознавців. Гармонійна роль мовлення - у необхідності забезпечення найкращого взаєморозуміння між людьми, конструктивного врегулювання конфліктів, об'єднання учасників спілкування. Володіння цими якостями особливо актуалізується для майбутніх юристів. Слушним є висловлювання Цицерона: “Скільки разів ми виступаємо, стільки разів над нами здійснюється суд”. Утім сьогоднішня система вищої освіти несправедливо мало уваги відводить формуванню культури українського мовлення майбутніх фахівців, розвитку мисленнєво-мовленнєвої діяльності оратора, формуванню полемічної майстерності студентаправознавця.

Переконані, що за умов актуалізації знань у галузі еристики (розділу риторики, що вивчає закони ефективного ведення суперечок, діалогічного та полілогічного мовлення) у процесі професійної підготовки майбутніх правознавців можна підвищити мовленнєву культуру особистості студента. Базовими тут є знання про нормативність українського мовлення, його культуру, полемічне мистецтво, а також уміння вести розгорнутий монолог з фахової проблематики, виробити власний ораторський стиль, виголошувати промову 3 використанням невербальних засобів впливу на аудиторію, застосовувати численні прийоми виразності у процесі підготовки тексту промови, уміння вести діалог, полілог, послуговуватися спілкувальним етикетом тощо.

Важливим на початку професійної підготовки у ЗВО є звернення уваги майбутніх фахівців на труднощі, які можуть виникнути у процесі мовленнєвої діяльності. Для цього доречно запропонувати студентам анкету (табл. 1). Попередньо проінструктувавши респондентів, а саме: проаналізуйте труднощі на основі їхньої важливості для подолання; цифрою 1 позначте те, що найбільше перешкоджає Вам у мовленнєвій діяльності, цифрою 2 - перешкоджає меншою мірою, цифрою 3 - труднощі, 3 якими Ви не зустрічаєтеся зовсім.

Усі комунікативні ознаки культури українського мовлення майбутніх правознавців тісно пов'язані між собою, вони зумовлюють справжню красу української мови. Досконале володіння мовою, iї нормами в процесі професійної мовленнєвої діяльності юриста й визначає його культуру мовлення, що передбачає передовсім досконале володіння нормами сучасної української мови, знаннями про стильове розмаїття мови, володіння багатим лексичним запасом тощо. Фахівець у галузі юриспруденції має бути ерудованим, знатися у всіх галузях науки, культури, мати 
Таблиця 1.

Анкета, спрямована на виявлення труднощів у мовленнсвій діяльності майбутніх правознавців

\begin{tabular}{|c|c|c|}
\hline № ח/П & Характеристика труднощів & Ранг \\
\hline 1 & $\begin{array}{l}\text { Важко стежити за нормативністю мовлення (правильне наголошування слів, } \\
\text { слововживання) }\end{array}$ & \\
\hline 2 & Важко визначитися з темою виступу & \\
\hline 3 & Труднощі на етапі формулювання задуму, створення концепції виступу & \\
\hline 4 & Важко дібрати початок та кінець виступу & \\
\hline 5 & Труднощі при підборі необхідного для промови матеріалу & \\
\hline 6 & Важко надати промові композиційної довершеності & \\
\hline 7 & Не вмію вербалізувати й редагувати промову & \\
\hline 8 & Важко дібрати доцільні приклади, щоб проілюструвати думку & \\
\hline 9 & Не вмію прикрашати промову художньо-виразними засобами (естетизувати текст) & \\
\hline 10 & Труднощі на етапі моделювання аудиторії & \\
\hline 11 & Важко адаптувати вже готову промову до певної аудиторії & \\
\hline 12 & Не можу подолати страх перед аудиторією & \\
\hline 13 & Важко застосовувати невербальне мовлення (управляти жестами, рухами, мімікою) & \\
\hline 14 & Не завжди вдається досягти бажаної емоційності та експресивності & \\
\hline 15 & $\begin{array}{l}\text { Важко стежити за культурою аргументації (втрачаю основну думку, відволікаюсь на } \\
\text { інше, другорядне, забуваю) }\end{array}$ & \\
\hline 16 & Не знаю, як зацікавити слухачів, завоювати увагу, викликати довіру & \\
\hline 17 & Важко налагодити зворотний зв’язок, установити контакт з аудиторією & \\
\hline 18 & Не вдається тримати “контакт очей” зі слухачами під час виступу & \\
\hline 19 & Не можу викликати слухачів на дискусію & \\
\hline 20 & $\begin{array}{l}\text { Розгублююся, коли хто-небудь зі слухачів зі мною не погоджується, починає } \\
\text { суперечку }\end{array}$ & \\
\hline 21 & Не вмію переконувати & \\
\hline 22 & $\begin{array}{l}\text { Не завжди пам’ятаю про культуру ведення суперечки, важко застосовувати } \\
\text { спілкувальний етикет }\end{array}$ & \\
\hline 23 & $\begin{array}{l}\text { Не вдається майстерно полемізувати, коли дошкуляють опоненти, є труднощі щодо } \\
\text { відповідей на запитання наприкінці промови }\end{array}$ & \\
\hline 24 & Є труднощі під час аналізу промови, важко рефлексувати & \\
\hline
\end{tabular}

базові знання з мистецтва полеміки тощо. Безумовною умовою його культурного потенціалу мають бути знання української та світової літератури, майбутній правознавець має знати багато крилатих висловів напам'ять, а також твори української та світової класичної літератури, щоб за необхідності скористатися ними у своїх промовах чи виступах.

Для поліпшення культури українського мовлення варто 3-поміж іншого застосовувати окремі вправи на релаксацію (розслаблення) дихання і звучання голосу; під час промови, бесіди, дискусії не тільки ретельно дбати про нормативність мовлення, а й користуватися всіма можливостями голосу, інтонації, застосовувати логічні наголоси, риторичні паузи, до прикладу, замість непотрібних слів-“бур'янів”; обдумувати кожну фразу, збагачуючи власний досвід через ораторську практику інших; виокремлювати ключову думку сповільненим темпом мовлення, підвищенням голосу тощо; варто постійно звертатися до словників, іншої довідкової літератури, навчатися на найкращих ораторських, акторських зразках (прослуховування записів, аналіз дієвості виступів тощо); постійно тренуватися, проговорювати "про себе" і вголос свій виступ, перед дзеркалом, на самоті, перед друзями, ширшою аудиторією, записувати свій виступ та аналізувати його; виховувати мовне чуття та як підсумок - виробляти власний стиль мовлення [1]. Це особливо важливо сьогодні, коли за умов правової держави авторитарний стиль змінюється демократичним, зростає роль конструктивного діалогу не тільки в політиці та пропаганді, а й у інших сферах суспільного життя, зок-рема в юридичній освіті. Невміння вести конструктивний діалог призводить до непотрібного протистояння і протидії сил, до гальмування демократичного розв'язання проблем.

Діалог як вид красномовства є дуже давнім. У Древній Греції і виникла еристика, яка є складнішим видом ораторського мистецтва, аніж монологічне красномовство, позаяк зазвичай учасникам діалогів і полілогів властиві різні погляди, суперечливі думки й емоції, а це потребує неабиякої уваги співрозмовників, підготовки, відповідного настрою, переконливих доказів, тактовності тощо. Еристика як риторика 
діалогічного мовлення виявляється в таких жанрах, як дискусія, полеміка, диспут, дебати, суперечка тощо. Для майбутніх правознавців вона має особливе значення, адже ефективне ведення професійних дискусій приведе до успішного розв'язання певних професійних проблем, унеможливить загострення конфлікту сторін тощо. У зв'язку із цим постає питання правильного ведення дискусій. Це насамперед стосується психології ведення дискусії, особливо мовної культури при цьому, позаяк чимало людей у ході суперечки не вміють дотримуватися елементарної мовленнєвої культури, не знають, як дібрати доречні мовні формули, не користуються мовленнєвим етикетом.

Важливо навчити майбутніх юристів культури ведення суперечок, використання необразливих, дипломатичних формулювань, сформувати уміння висловлювати лаконічно свою думку, не припускатися двозначного трактування власних висловлювань і позицій. Неприпустимо під час дискусій використовувати недозволені методи ведення суперечок: ображати один одного, натякати на якісь певні негативні сторони один одного, не маючи конкретних доказів чи співвідносити до суперечки ті речі, які не мають жодного логічного стосунку до питань, які обговорюються [3; 4].

Ознайомлюючи студентів-правознавців 3 мовленнєвою діяльністю під час ведення суперечок, доречно надати інформацію про критерії оцінювання власних риторичних умінь [3; 4] (табл. 2).

Риторика діалогічного мовлення випрацювала певні правила, технологію і культуру еристики, 3 якими потрібно ознайомити майбутніх правознавців. Наведемо окремі з них, які назвали “золотими правилами еристики”:
- не варто дискутувати чи сперечатися 3 приводу тем, понять, що є аксіомами і не потребують доведення. Такі теми не дають простору, перспективи для розгортання думки, дискусія “захлинеться”, опоненти не зможуть себе показати. Варто обирати теми, що “потребують роботи думки" (Аристотель);

- доречно пам'ятати, що основною і найкращою метою всіх без винятку суперечок є змусити супротивника думати так, як ви, прийняти вашу позицію, тому не варто викладати відразу всі положення, тези чи аргументи (вибрати доцільно одне, але добре сформульоване положення, відтак послідовно додавати по одному тези й аргументи, але завжди мати про запас що сказати);

- не хвилюватися, побороти страх перед публічним виступом, оскільки надмірні хвилювання пригальмують вашу думку, адже тут, як у монолозі: що більше хвилювання, то гірше думається і висловлюється; переляканого пошкодують, але не пошанують);

- на початку суперечки доцільно домовитися про метамову (терміни, дефініції, поняття, категорії, класифікації, джерела тощо);

- не намагайтеся все заперечувати; використайте прийом умовного схвалення, за якого можна погодитися з певними положеннями опонента (станьте ніби на його позицію, але потім заперечте йому в найістотнішому);

- уникайте суперечок про те, чого добре не знаєте. Учіться вчасно переводити розмову в інше русло (майте для цього якісь заготовки, свіжі новини, події, факти, сенсації, приказки, дотепи тощо);

- якщо дискусія чи полеміка публічна, не забувайте про аудиторію, залучайте ії до паритету (колеги знають.., слухачі підтвердять.., студенти пам'ятають...), але дуже шанобливо;

Таблиця 2.

Оцінювання вміння ведення суперечки

\begin{tabular}{|c|c|c|}
\hline $\begin{array}{l}\text { № } \\
\Pi / \Pi\end{array}$ & Критерії оцінювання умінь вести суперечку & $\begin{array}{l}\text { Бали: від } \\
1 \text { до } 5\end{array}$ \\
\hline 1 & $\begin{array}{l}\text { Актуальність предмета суперечки для певної ситуації, для учасників суперечки, } \\
\text { для слухачів }\end{array}$ & \\
\hline 2 & Компетентність та ерудиція мовця щодо предмета суперечки & \\
\hline 3 & $\begin{array}{l}\text { Ефективність стратегії впливу на опонента: цільової установки, формулювання } \\
\text { тези (контртези), аргументів (підаргументів) }\end{array}$ & \\
\hline 4 & Ефективність прийомів захисту в суперечці & \\
\hline 5 & Коректність та ефективність запитань & \\
\hline 6 & Об’єктивність відповідей & \\
\hline 7 & Мовленнєва культура & \\
\hline 8 & Володіння мовленнєвим етикетом & \\
\hline 9 & Уміння завершувати спір, підводити підсумки & \\
\hline 10 & Уміння програвати & \\
\hline
\end{tabular}


не висловлюйте при цьому негативних оцінок. Намагайтеся основні положення, поняття, дефініції, ознаки повторити підкреслити в різних контекстах кілька разів $з$ тим, щоб ваша позиція запам'яталася і закріпилася;

- пам'ятайте, що, як і в монологічній промові, головним у діалогічному спілкуванні є тези й аргументи (вони мають бути дуже короткими, точними і доречними);

- аргументацію слід будувати на причиновонаслідкових зв'язках і законах формальної логіки. Найкращими аргументами в суперечці $є$ доказові положення, точні фактиі цифри, конкретні явища, події;

- завжди починайте розмову якомога приємнішим, спокійнішим і тихішим тоном, щоб був простір для наростання суперечки і щоб завжди відчували, що є можливість підвищення тону, але ніколи не підходьте до межі підвищення тону, не зривайтеся на крик. Зробіть очевидну паузу i, якщо не зможете приємним, то хоча б байдужим тоном обов'язково завершіть розмову (на жаль, Ви мене не зрозуміли; шкода, щуо ми не домовилися; ие втрата для мене, як, можливо, і для Вас; продовжимо розмову іншим разом; шкода, щчо ніхто з нас не переконав іншого);

- у розпалі суперечки, коли можуть злетіти з уст недобрі, злі слова, негайно зупиніться (глибоко дихайте носом). Пам'ятайте, що після будь-якого конфлікту із суперником доведеться миритися і щось прощати, тоді самому буде незручно за грубі слова. Коли настрій поганий, не дискутуйте, позаяк усе одно програєте, й уникайте ситуацій “з'ясування стосунків”; продумайте тактику відступу, відкладання на потім - на випадок неуспіху чи поразки (Сьогодні справді ще не час, але...; Ми до иьього ще повернемося пізніше, а зараз...; Ви самі з часом переконаєтеся...); у випадку поразки ведіть себе чемно і гідно. Придумайте варіанти: вчуся дискутувати; хотів переконатися в тому, щзо Ви знавещь;; Ви для мене зразок для наслідування; я поступаюсь Вам, залишаючись на своїх позиціях, власних переконаннях; $i$ все ж аргументи не вичерпані тощо);

- у всіх випадках, навіть образливих для вас, пам'ятайте про мовний етикет. Приязно привітавшись поширеним звертанням, зробіть опонентові комплімент, запевніть його у своїй повазі, почніть розмову з нейтральних коротких тем (погода, час, дорога, люди), непомітно і м'яко підходьте до основної теми. У процесі дискусії також не забувайте кілька разів звернутися до опонента (на ім'я, ім'я і по батькові, шановний, пане, друже, мій опоненте, шановний візаві тощо), перепросіть, запропонуйте щось, висловіть свої наміри в бажальній формі (я б хотів прочути, чи міг би я спитати Вас, я б хотів з'ясувати у $B a c)$. Пам'ятайте про ввічливість і пошанні мовні формули навіть тоді, коли програєте суперечку. Якщо програєте суперечку, то робіть це достойно і красиво - це одна з ваших перемог [1, 60-65; 4].

Висновки та перспективи подальших досліджень.Діалогічне (полілогічне) красномовство майбутніх правознавців має важливе значення у процесі їхньої професійної підготовки. Сьогодні в суспільстві актуалізується еристика як наука про ведення суперечок, тому у ЗВО варто ширше використовувати іiі як засіб формування українського мовлення фахівців-юристів. Риторика діалогічного мовлення виробила певні правила, технологію і культуру еристики. У своїй професійній мовленнєвій діяльності майбутні правознавці повинні досконало володіти правилами ведення бесіди, дискусії, суперечки, диспуту, дебатів тощо. Важливе місце під час проведення різного роду суперечок посідає культура мовлення. “Золоті правила еристики” мають стати засадничими у професійній діяльності майбутніх юристів.

\section{ЛІТЕРАТУРА}

1. Білавич Г. Основи риторики. Івано-Франківськ, 2018.208 c.

2. Височан 3. Компетентнісний підхід формування культури українського діалогічного мовлення майбутніх правознавців. Молодь і ринок. 2019. №1. C. $136-140$.

3. Коваленко С. Сучасна риторика. Навчальнопрактичний посібник. Тернопіль, 2007. 180 с.

4. Культура ведення дебатів. Харків, 1988. 190 с.

5. Яворська Г. Базові компетентності майбутніх правознавців. Наукові записки Міжнародного гуманітарного університету: збірник. Одеса: Фенікс, 2016. Вип. 25. С.220-226.

\section{REFRERENCES}

1. Bilavych, H. (2018). Osnovy rytoryky [Fundamentals of rhetoric]. Ivano-Frankivsk, 208 p. [in Ukrainian].

2. Vysochan, Z. (2019). Kompetentnisnyi pidkhid formuvannia kultury ukrainskoho dialohichnoho movlennia maibutnikh pravoznavtsiv [Competency-based approach for the formation of culture of ukrainian dialogue speech of future lawyers]. Youth \& market, no.1, pp. 136140. [in Ukrainian].

3. Kovalenko, S. (2007). Suchasna rytoryka [Modern rhetoric]. Educational and practical guide.Ternopil, 180 p. [in Ukrainian].

4. Kultura vedennia debativ (1988). [The culture of debate]. Kharkiv, 190 p. [in Ukrainian].

5. Yavorska, H. (2016). Bazovi kompetentnosti maybutnikh pravoznavtsiv [Basic competences of future lawyers]. Scientific notes of the International Humanitarian University. Odesa, vol. 25, pp. 220 226. [in Ukrainian].

Стаття надійшла до редакції 29.09.2020 